\title{
PENDEKATAN MULTIKULTURAL DALAM PEMBELAJARAN BAHASA INGGRIS MELALUI MEDIA DONGENG PADA ANAK USIA DINI
}

\author{
Widhiya Ninsiana \\ Institut Agama Islam Negeri (LAIN) Metro \\ Jl. Ki Hajar Dewantara 15A Iring Mulyo Kota Metro \\ e-mail: tantowidi@yahoo.co.id
}

\begin{abstract}
Indonesia is a multicultural country, because it consists of various cultures, customs, and a variety of habits. These components are generally bonded together (integrated/embedded) with ethnicity, language, and culture. The use of foreign languages, especially English, in all its forms is related teaching foreign languages in formal and informal education in Indonesia. Even some foreign language has been introduced on early childhood. Seeing this phenomenon, educators must have a knowledge of foreign languages, willingness and skills to introduce and involve all educate into a global context. The introduction and engagement multicultural (cross-cultural disposition) that should be conducted transformative or practical experience (cross-cultural encounter) in learning English language, such as a fairytale. The multicultural approach in English learning by fairytale on early childhood will make the children more tolerant the other cultures.
\end{abstract}

Keyword: multicultural, fairlytale, early childhood

\begin{abstract}
Abstrak
Indonesia adalab negara multikultural, karena terdiri dari berbagai budaya, adat istiadat, dan berbagai kebiasaan. Komponen-komponen ini pada umumnya terikat bersama (terpadu / tertanam) dengan etnisitas, bahasa, dan budaya. Penggunaan bahasa asing, terutama bahasa Inggris, dalam segala bentuknya terkait pengajaran bahasa asing dalam pendidikan formal dan informal di Indonesia. Bahkan beberapa bahasa asing telah diperkenalkan pada masa kanak-kanak. Melihat fenomena ini, pendidik harus memiliki pengetahuan bahasa asing, kemauan dan keterampilan untuk mengenalkan dan melibatkan semua terdidik ke dalam konteks global. Pengenalan dan keterlibatan multikultural (disposisi lintas budaya) yang harus dilakukan pengalaman transformatifatau praktis (jumpa lintas budaya) dalam belajar bahasa Inggris, seperti dongeng. Pendekatan multikultural dalam pembelajaran bahasa Inggris oleh dongeng pada masa kanak-kanak akan membuat anak-anak lebib toleran terhadap budaya lain
\end{abstract}

Kata kunci: multikultural, dongeng, anak usia dini 


\section{Pendahuluan}

Perhatian pendidikan pada anak usia dini merupakan prioritas utama dalam tumbuh kembang anak. Karena usia anak pada saat itu dikenal dengan masa keemasan 'golden age'. Masa keemasan ditandai dengan perkembangan motorik dan kognitif anak. Perkembangan kognitif anak menjadi perhatian penuh orangtua karena pada usia ini stimulus anak mulai merespon dengan baik sehingga perlunya para orangtua dan guru memberikan dan menciptakan pengajaran dan pembelajaran yang berkualitas pada anak.

Menurut beberapa hasi penelitian bahwa pembelajaran bahasa kedua atau bahasa asing dalam hal ini bahasa Inggris sangat dianjurkan dipelajari oleh anak usia dini. Pembelajaran bahasa Inggris sedini mungkin diajarkan pada anak sehingga anak akan mengembangkan kemampuan bahasa yang dimilikinya. Anak akan menjadi bilingual yang baik dalam berbahasa, yaitu bahasa Indonesia dan bahasa Inggris. Kemampuan bilingual atau dwibahasa adalah kemampuan menggunakan dua bahasa. Kemampuan bilingual tidak hanya dalam berbicara dan menulis tetapi juga dapat mempresentasikan dan mengkomunikasikan dengan orang lain melalui lisan dan tulisan. Melalui kemampuan bilingual anak akan memiliki pengalaman dengan budaya luar selain budaya yag dimilikinya. Pemberian materi ajar bahasa Inggris dalam bentuk dongeng adalah satu cara untuk mengembangkan kemampuan bilingual anak. Dongeng bahasa Inggris biasanya menampilkan unsur budaya lokal. Mempelajari budaya lokal dalam bentuk lintas budaya membuat anak akan memahami budaya daerah lain dan tidak mengalami schok culture dan anak akan memiliki sikap toleran terhadap budaya lain.

\section{Pendidikan Anak Usia Dini}

Landasan dasar mulai dibentuknya watak dan karakter anak pada jenjang pendidikan dimulai dari usia 0-6. Pada usia-usia inilah mudah bagi para guru untuk dapat membentuk karakter anak menjadi manusia yang lebih baik dikemdian hari. Di usia 0-6 tahun anak sebagai mana yang dinyatakan oleh Boediono bahwa :

"Anak usia dini memiliki pertumbuhan dan perkembangan yang unik, khususnya fisik (koordinasi motorik halus dan kasar), intelegensi (daya pikir, daya cipta, kecerdasan emosi, kecerdasan spiritual), sosial emosional (sikap dan perilaku serta agama), bahasa dan komunikasi yang khusus sesuai dengan tingkat pertumbuhan dan perkembangan anak"

Pada anak usia dini, pembelajaran bahasa Inggris bertujuan memotivasi mereka untuk berani dan percaya diri berbicara dalam bahasa Inggris baik secara lisan dan tulisan.

Menurut pakar bahasa bahwa proses pembelajaran bahasa dibagi atas tiga aliran, yaitu ${ }^{2}$;

\section{a. Aliran behaviorisme}

Aliran behaviorisme muncul karena ketidakpuasan terhadap teori psikologi dan teori mental state. Behaviorisme adalah studi mengenai kelakuan manusia. Kelakuan manusia yang dipelajari adalah bagaimana belajar akan mempengaruhi tingkah laku manusia sebagai hasil dari pengalaman, karena belajar merupakan akibat stimulus dan respon.

Dalam belajar bahasa, teori ini memandang bahwa pemerolehan bahasa seseorang diperolehnya karena adanya kesempatan untuk mengembangkan dirinya melalui latihan-latihan berbahasa langsung dengan sekelilingnya. Adanya stimulus dan respon yang dimilikinya dan adanya motivasi dalam diri sianak untuk belajar bahasa serta didukung oleh lingkungan sekitarnya akan memberikan dampak yang positif bagi pemerolehan bahasa sianak tersebut. Faktor lingkungan dan faktor kebiasaan memberikan pengaruh yang besar terhadap

1 Boediono. 2002. Kurikulum dan Hasil Belajar. Jakarta : Depdiknas.h.4

2 Brown, H.D. Principles of Language Learning and Teaching: Englewood Cliff:Prentice Hall. 1987. h.16-24 
keberhasilan seseorang memperoleh dan menguasai bahasa kedua ${ }^{3}$.

\section{b. Aliran Navistik}

Nativisme berasal dari kata Nativus yang berarti kelahiran. Istilah nativisme beranjak dari pernyataan bahwa pembelajaran bahasa ditentukan oleh bakat. Teori ini muncul dari filsafat nativisma (terlahir) sebagai suatu bentuk dari filsafat idealisme dan menghasilkan suatu pandangan bahwa perkembangan anak ditentukan oleh hereditas, pembawaan sejak lahir, dan faktor alam yang kodrati. Anak tidak sekadar meniru bahasa yang ia simak, tetapi ia juga mampu menarik kesimpulan dari pola yang ada. Karena pada dasarnya anak memiliki sistem bahasa yang disebut Perangkat Penguasaan Bahasa (Language Acquisition Devise/ LAD). Mc.Neil via Brown mendeskripsikan LAD itu terdiri atas empat bakat bahasa, yakni: 1) Kemampuan untuk membedakan bunyi bahasa dengan bunyi-bunyi yang lain. 2) Kemampuan mengorganisasikan peristiwa bahasa ke dalam variasi yang beragam. 3) Pengetahuan adanya sistem bahasa tertentu yang mungkin dan sistem yang lain yang tidak mungkin. 4) Kemampuan untuk mengevaluasi sistem perkembangan bahasa yang membentuk sistem yang mungkin dengan cara yang paling sederhana dari data kebahasaan yang diperoleh ${ }^{4}$.

\section{c. Aliran Kognitivistik}

Cognition atau lebih dikenal dengan istilah cognitive adalah suatu proses perolehan, penataan dan penggunaan pengetahuan ${ }^{5}$. Kognisi adalah kegiatan mental dalam memperoleh, mengolah, mengorganisasi, dan meggunakan pengetahuan, sedangkan proses yang paling utama dalam

3 Stephen D.Krashen, "Laterization, Language, Learning and the Critical Period: Some New Evidence.” Language Learning, Vol.23.1972. .h.40

4 Ibid..h.22

5 Muhibbin Syah, Psikologi Belajar . Jakarta: PT. RajaGrafindo Persada. 2007.h..22 kognisi meliputi mendeteksi, menginterpretasi, mengklasifikasi, dan mengingat informasi, mengevaluasi gagasan, menyaring prinsip dan mengambil kesimpulan segala macam pengalaman yang di dapat dalam kehidupannya ${ }^{6}$

Aliran kognivistik mengatakan bahwa belajar merupakan suatu proses perubahan persepsi dan pemahaman yang tidak selalu berbentuk tingkah laku yang dapat dikur dan diamati. Perubahan tingkah laku seseorang tidak tampak sesungguhnya hanyalah refleksi dari perubahan internalisasi persepsi dirinya terhadap sesuatu yang sedang diamati dan dipikirkannya ${ }^{7}$

Belajar adalah perubahan persepsi dan pemahaman. Belajar tidak selalu berbentuk perubahan tingkah laku yang bisa diamati. Kemampuan belajar bahasa tidak merupakan kemampuan bawaan yang bersifat khusus, melainkan merupakan bagian integral dari kemampuan kognitif anak-anak. Perkembangan kognitif anak mulai berkembang pada usia 7-12 tahun. Pada tingkatan usia ini, tingkatan berpikir anak pada hal yang konkret. Kemampuan bahasa sudah dimiliki anak usia dini. Bahasa yang digunakan sudah diajarkan mulai dari lingkungan rumah dan lingkungan formal. bahasa bukanlah suatu ciri alamiah yang terpisah, melainkan salah satu di antara beberapa kemampuan yang berasal dari kematangan kognitif. Urutan-urutan perkembangan kognitif menentukan urutan perkembangan bahasa.

Kelompok usia yang sangat unik dalam kehidupan manusia adalah proses tumbuh kembangnya anak. Proses tumbuh kembangnya anak terjadi pada usia peka yang dikenal dengan nama masa keemasan atau dikenal dengan nama golden age. Pada masa peka ini kecepatan pertumbuhan

6 Paul Henry, dkk, Perkembangan dan Kepribadian Anak, jilid II, Terjemahan Med Meitasari Tjandrasa Jakarta, Erlangga, 1994. h.194

7 Hamzah B. Uno,Orientasi Baru Dalam Psikologi Pembelajaran, Jakarta: Bumi Aksara, 2006. h. 53 
otak anak sangat tinggi hingga mencapai 50 persen dari keseluruhan perkembangan otak anak selama hidupnya. Masa, golden age merupakan masa yang sangat tepat untuk menggali segala potensi kecerdasan anak sebanyak-banyaknya. Dalam standar kompetensi anak usia dini ini terjadi pengembangan aspek-aspek sebagai berikut: moral dan nilai-nilai agama, sosial-emosi dan kemandirian, bahasa, kognitif, fisik-motorik dan seni.

Anak usia dini melalui beberapa aspek perkembangan anak dibagi atas ;

\section{a. Perkembangan Motorik}

Perkembangan motorik pada anak-anak merupakan perkembangan yang sangat penting dalam kehidupan manusia.Perkembangan motorik akan seiring sejalan juga dengan perkembangan fisik si anak. Keterampilan motorik pada anak dibagi $\operatorname{atas}^{8}$;

1. Keterampilan lokomotor: berjalan, berlari, meloncat, meluncur.

2. Keterampilan nonlokomotor: mengangkat, mendorong, melengkung, berayun, menarik.

3. Keterampilan memproyeksi dan menerima/menangkap benda: menangkap, melempar

Perkembangan motorik pada anak usia dini meliputi perkembangan motorik kasar dan motorik halus. Motorik kasar adalah gerakan tubuh yang menggunakan otot-otot besar atau sebagian besar atau seluruh anggota tubuh yang dipengaruhi oleh kemantangan anak itu sendiri. Contohnya kemampuan duduk, menendang, berlari, naik turun tangga, dan sebagainya. Motorik halus adalah gerakan yang menggunakan otot-otot halus atau sebagian anggota tubuh tertentu, yang dipengaruhi oleh kesempatan untuk belajar dan berlatih. Misalnya, kemampuan memindahkan

8 Sujiono, Bambang, metode pengembangan fisik, Tangerang Selatan:Universitas Terbuka, 2015.h.1.3 benda dari tangan, mencorat-coret, menyusun balok, menggunting, menulis, dan sebagainya. Adapun perkembangan motorik kasar dan halus pada anak usia dini atau pra-sekolah dapat dilihat pada tabel di bawah ini;

\section{Perkembangan Motorik Kasar dan Motorik Halus pada Anak Usia Prasekolah ${ }^{9}$}

\begin{tabular}{|c|c|c|}
\hline Usia & $\begin{array}{l}\text { Perkembangan } \\
\text { Motorik Kasar }\end{array}$ & $\begin{array}{l}\text { Perkembangan } \\
\text { Motorik Halus }\end{array}$ \\
\hline $\begin{array}{l}3-4 \\
\text { tahun }\end{array}$ & $\begin{array}{l}\text { Berjalan naik turun } \\
\text { tangga, memilih } \\
\text { makanan, berdiri } \\
\text { dengan satu kaki, } \\
\text { melompat, berputar, } \\
\text { menangkap bola, dan } \\
\text { mengayuh sepeda } \\
\text { roda tiga. }\end{array}$ & $\begin{array}{l}\text { Melepas dan } \\
\text { mengancingkan } \\
\text { baju, makan sendiri, } \\
\text { menggunakan } \\
\text { gunting, dan } \\
\text { menggambar wajah. }\end{array}$ \\
\hline $\begin{array}{l}4-5 \\
\text { tahun }\end{array}$ & $\begin{array}{l}\text { Naik turun tangga } \\
\text { tanpa berpegangan, } \\
\text { berjalan dengan } \\
\text { ritme kaki yang } \\
\text { sempurna, memutar } \\
\text { tubuh, melempar } \\
\text { dan menangkap } \\
\text { bola, meyetir sepeda } \\
\text { roda tiga dengan } \\
\text { kecepatan cukup dan } \\
\text { luwes. }\end{array}$ & $\begin{array}{l}\text { Bisa menggunakan } \\
\text { garpu dengan } \\
\text { baik, menggunting } \\
\text { mengikuti garis, dan } \\
\text { menirukan gambar } \\
\text { segitiga. }\end{array}$ \\
\hline $\begin{array}{l}5-6 \\
\text { tahun }\end{array}$ & $\begin{array}{l}\text { Menunjukkan } \\
\text { perubahan yang } \\
\text { cepat: bertambah } \\
\text { jauh melempar } \\
\text { bola dan cekatan } \\
\text { menangkapnya, } \\
\text { mengendarai sepeda } \\
\text { dengan bergaya atau } \\
\text { bervariasi. }\end{array}$ & $\begin{array}{l}\text { Mampu } \\
\text { menggunakan pisau } \\
\text { untuk memotong } \\
\text { makanan-makanan } \\
\text { lunak, mengikat } \\
\text { tali sepatu, bisa } \\
\text { menggambar orang } \\
\text { dengan enam titik } \\
\text { tubuh, dan bisa } \\
\text { menirukan sejumlah } \\
\text { angka, dan kata } \\
\text { sederhana. }\end{array}$ \\
\hline
\end{tabular}

9 Suyadi. 2010. Psikologi Belajar Pendidikan Anak Usia Dini. Yogyakarta: Pedagogia.h.71 


\section{b. Perkembangan berfikir/kognitif}

Faktor kognitif mempunyai peranan penting bagi keberhasilan anak dalam belajar, karena sebahagian besar aktivitas dalam belajar selalu berhubungan dengan masalah mengingat dan berfikir. Karena berhuungan dengan masalah mengingat dan berpikir, maka pegembangan kognitif anak usia dini diarahkan pada pengembangan Auditory, Visual, Taktil, Kinestik. Aritmatika, Geometri, dan Sains. Pertama, Pengembangan Auditory AUD. Pada pengembangan kemampuan auditory, anak usia dini mulai menyimak dan memahami kumpulan bunyi suatu benda, kosakata atau kalimat yang memiliki makna dala topik tertentu.Kemampuan menyimak anak usia dini merupakan dasar dalam proses mempelajari pengetahuan. Mendengarkan musik, mendengarkan dongeng, bertepuk tangan saat menyanyi, mengenal asal suara dan mengetahui nama benda yang dibunyikan merupakan pengembangan kemampuan auditory anak. Kedua, kemampuan anak dalam pengembangan visual. Pengembangan visual anak berhubungan dengan penglihatan, pengamatan, perhatian, tangapan, serta persepsi anak terhadap lingkunagn sekitarnya. Contoh pengembangan visual seperti mengenali benda-benda sehari-hari, membandingkan benda-benda dari yang sederhana menuju ke yang lebih kompleks, mengetahui benda dari ukuran, bentuk, atau dari warnanya, mengetahui adanya benda yang hilang apabila ditunjukkan sebuah gambar yang belum sempurna atau janggal, menjawab pertanyaan tentang sebuah gambar seri dan atau lainnya, menyusun potongan teka-teki mulai dari yang sederhana sampai ke yang lebih rumit, mengenali namanya sendiri bila tertulis dan mengenali huruf dan angka. Ketiga, pengembangan taktil. Pengembangan taktil anak usia dini adalah kemampuan yang berhubungan dengan indera peraba (Tekstur) anak usia dini. Kemampuan yang dikembangkan, antara lain: mengembangkan kesadaran akan indera sentuhan, mengembangkan kesadaran akan berbagai tekstur mengembangkan kosa kata untuk menggambarkan berbagai tekstur seperti tebal-tipis, halus-kasar, panas-dingin, dan tekstur kontras lainnya, Keempat, pengembangan kinestetik. Pengembangan kinestetik anak usia dini adalah kemampuan yang berhubungan dengan kelancaran gerak tangan atau keterampilan atau motorik halus anak usia dini yang mempengaruhi perkembangan kognitif. Contoh pengembangan kinetetik yaitu adalah menjiplak huruf-huruf geometri, melukis dengan cat air, menjahit dengan sederhana, merobek kertas koran, menciptakan bentuk-bentuk dengan balok, membuat gambar sendiri dengan berbagai media, menjiplak bentuk lingkaran, bujur sangkar, segitiga atau empat persegi panjang, memegang dan menguasai sebatang pensil, menyusun atau menggabungkan potongan gambar atau teka-teki dalam bentuk sederhana, mampu menggunakan gunting dengan baik, dan mampu menulis, melukis dengan jari (Finger Painting), melukis dengan cat air, mewarnai dengan sederhana, menggunting, menjiplak, berlari, melompat dan lain-lain. Kelima, pengembangan aritmetika. Kemampuan ini diarahkan pada kemampuan berhitung dan matematika. Kemampuan yang dikembangkan, antara lain, mengenali atau membilang angka, menyebut urutan bilangan, menghitung benda, mengenali himpunan dengan nilai bilangan berbeda, memberi nilai bilangan pada suatu himpunan benda, mengerjakan atau menyelesaikan operasi penjumlahan, pengurangan, dengan menggunakan konsep dari kongkrit keabstrak, menghubungkan konsep bilangan dengan lambing bilangan, dan menciptakan bentuk benda sesuai dengan konsep bilangan. Keenam, pengembangan geometri. Pengembangan geometri anak usia dini adalah kemampuan yang berhubungan dengan konsep bentuk dan ukuran. Adapun kegiatan ini seperti panjang pendek, besar kecil,tinggi rendah, dan lain-lain. Terakbir, Pengembangan sains permulaan. Pengembangan sains permulaan anak usia dini adalah kemampuan yang berhubungan dengan berbagai percobaan atau demonstrasi sebagai suatu pendekatan secara Sainstific atau Logis. Proses penemuan ilmiah 
dapat terjadi dimana saja dan kapan saja seperti Cara mengajarkan sains pemulaan dengan mengajak anak ke kebun atau ke taman. Banyak hal yang dapat diamati anak di alam sekitarnya. Adapun kemampuan yang akan dikembangkan, antara lain: 1) Mengeksplorasi berbagai benda yang ada di sekitar, 2) Mengadakan berbagai percobaan sederhana, dan 3) Mengkomunikasikan apa yang telah diamati dan diteliti.

\section{c. Perkembangan Bahasa}

Perkembangan kemampuan bahasa anak usia dini dibagi atas dua bagian, yaitu pengembngan kemampuan bahasa lisan (berbicara dan menyimak) dan pengembangan kemampuan bahasa tuis (membaca dan menulis (membaca dan menulis) ${ }^{10}$. Menyimak merupakan keahlian dasar pada manusia sehingga itu menyimak memegang peranan penting pada kehidupan anak, Kemampuan menyimak dapat dilakukan dengan memberikan stimulasi dan latihan secara optimal kepada anak. Melalui kemampuan menyimak anak akan belajar mengekspresikan diri secara lisan dalam menyampaikan pendapat, perasaan, ide dan sebagainya.

Perkembangan kemampuan membaca dan menulis pada anak usia dini hendaklah memperhatikan perkembangan motorik halus si anak. Apakah motorik halusnya sudah berkembang dengan baik. Salah Satu contoh perkembangan motorik anak adalah anak dapat memegang pensil dengan sempurna, jari-jemarinya sudah dapat digunakan dengan sempurna dalam kegiatan tulis-menulis. Apabila anak sudah sempurna menggerakkan alat tulis tersebut, maka anak mudah untuk meniru bentuk tulisan. Kemampuan anak untuk dapat meniru bentuk tulisan akan memberikan dampak juga kepada anak untuk mengenal huruf. Dari pengenalan huruf kepada

${ }^{10}$ Wiwik Pudjaingsih. Metode Pengembangan Bahasa : Penerapannya pada Pembelajaran Berbasis Tema dan Sentra di Taman Kanak-kanak.Jurnal Pena. Vol.3 No.2. Desember 2013. ISSN.2089-3973 anak membeerikan konstribusi yang positif kepada anak untuk belajar membaca.

\section{d. Perkembangan Sosial}

Perkembangan sosial pada masa kanak-kanak telah dilakukan anak sejak kecil. Hubungan emosianal anak dengan lingkungannya membentuk pribadi anak yang handal berdaptasi dengan lingkungan di sekitarnya. Pola perilaku sosial ini seperti kerjasama, persaingan, kemurahan hati, hasrat akan penerimaan sosial, simpati, empat, ketergantungan, sikap ramah, sikap tidak mementingkan diri sendiri, meniru, perilaku kelekatan ${ }^{11}$.

Perkembangan sosial berarti perkembangan tingkah laku anak menyesuaikan diri dengan aturan-aturan yang berlaku di masyarakat.Dalam menyesuaikan dengan lingkungannya anak dituntut untuk mampu menyesuaikan diri dengan berbagai tatanan, seperti keluarga, sekolah dan teman sepermainannya. Salah satu ciri berkembangnya aktivitas sosial pada masa kanak-kanak awal ini ditandai dengan adanya hubungan atau kontak sosial baik dengan keluarga maupun dengan orangorang di luar keluarganya terutama dengan anakanak seusianya. Mulai belajar untuk menyesuaikan diri dan bekerja sama dengan teman-temannya ${ }^{12}$

\section{Pendidikan Multikultural dan Lintas Budaya pada Anak Usia Dini \\ Penggunan bahasa asing, terutama bahasa} Inggris, dalam segala bentuknya di Indonesia sangat terkait dengan pengajaran bahasa asing di pedidikan formal maupun informal. Beberapa bahasa asing telah diperkenalkan bahkan sejak usia dini.

Pengenalan bahasa Inggris khususnya lintas budaya bagi anak usia dini sangatlah penting. Dedi Irwansyah dalam salah satu tulisan di

11 Hurlock, Elizabeth B. 1998. Perkembangan Anak jilid 1. Jakarta: Erlangga Jakarta: Erlangga. h. 252

12 Sutjihati Somantri, Psikologi Anak Luar Biasa, 2006. Bandung: PT.Refika Aditama. h..42 
jurnalnya menyetujui pernyataan sebelumnya, yaitu penggunaan bahasa Inggris pada anak usia dini. Pengenalan lintas budaya adalah proses belajar budaya asing ${ }^{13}$. Pemahaman lintas budaya berarti ia akan mengenal budayanya sendiri dan toleran dengan budaya luar yang bukan budayanya sendiri ${ }^{\mathrm{a}}$ Pendekatan lintas budaya dalam pembelajaran bahasa Inggris pada anak usia dini sangat dianjurkan. Pembelajaran bahasa Inggris dengan memasukkan unsur budaya pada materi ajar khusus budaya setempat memberikan konstribusi bagi anak untuk mengembangkan karakter anak menjadi lebih baik di kemudian hari. Cakupan materi ajar yang bersumber dari budaya lokal yang dimaksud adalah aturan-aturan, nilai-nilai atau kaidah-kaidah yang sering dipraktekkan di masyarakat, kebiasaan di rumah tangga, kegiatan keagamaan, serta bentuk fisik seperti tempat pariwisata, objek pariwisata, tempat ibadah, fasilitas umum, penduduk lokal, keluarga dan lain sebagainya.

Melihat fenomena di atas, ditarik kesimpulan bahwa adanya keterkaitan antara bahasa dan budaya khususnya dalam pembelajaran bahasa kedua atau bahasa asing. Karena pada dasarnya bahasa tidak semata-mata mempelajari strukturalnya saja, tetapi juga komunikatif dan bersifat sosial. Hubungan sosial akan semakin rumit dan kompleksitas bila bahasa dihubungkan dengan linguistik dan aspekaspek sosialkultural suatu bangsa.

Memahami budaya asing melalui pemahaman lintas budaya bukan berarti untuk membiasakan diri hidup dengan budaya itu, melainkan untuk lebih mengenal dan memahami budaya sendiri. Dengan lain perkataan, pemahaman lintas budaya bagi anak usia dini akan menanamkan sikap evaluatif dan toleran terhadap budaya asing. Dalam proses lintas budaya ini, budaya sendiri berfungsi sebagai acuan cara pandang. Dengan demikian seeseorang dapat memiliki sudut pandang budaya ketiga

13 Dedi Irwansyah.Pendidikan Multikultural dan Pengajaran Bahasa Asing. Jurnal Addin, Vol. 7, No. 1, Februari 2013 yang sekaligus dapat berperan sebagai jembatan psikologis antara budaya sendiri dan budaya asing yaitu : (1) memiliki kepekaan budaya yang berbeda dengan budaya kita; (2) toleran, dan bijaksana dalam menyikapi perbedaan budaya, (3) memahami persepsi orang lain; dan (5) memperlihatkan empati dan hormat.

\section{Pembahasan}

\section{Pentingnya Pendidikan Multikultural pada} Anak Usia Dini

Undang-undang nomor 20 tahun 2003 tentang Sistem Pendidikan Nasional Pasal 1 ayat 14 menyatakan bahwa: pendidikan anak usia dini adalah suatu upaya pembinaan yang ditujukan kepada anak sejak lahir sampai dengan usia enam tahun yang dilakukan melalui pemberian rangsangan pendidikan untuk membantu pertumbuhan dan perkembangan jasmani dan rohani agar anak memiliki kesiapan dalam memasuki pendidikan lebih lanjut. Selanjutnya pasal 28 menyatakan bahwa pendidikan anak usia dini diselenggarakan melalui jalur pendidikan formal, nonformal, dan/ atau informal $1^{14}$.

Hal ini diperkuat lagi oleh PERMEN 58 Tahun 2009 tentang Standar Pendidikan Anak Usia Dini menguraikan dalam Standar Tingkat Pencapaian Perkembangan Anak, lingkup perkembangan anak usia dini khusunya di Taman Kanak-kanak adalah nilai-nilai agama dan moral, fisik, kognitif, bahasa dan sosial emosional ${ }^{15}$.

Anak usia dini memiliki rentang usia yang dikenal dengan 'Golden Age'. Pada usia emas ini anak menyerap informasi yang dimilikinya tanpa melalui proses penyerapan terlebih dahulu. $\mathrm{Hal}$ ini disebabkan oleh kognitif yang dimiliki anak belumlah sempurna, sehingga itu pada usia emas ini

${ }^{14}$ Undang-Undang No. 20 Tahun 2003. Tentang Sistem Pendidikan Nasional. Jakarta: Gramedia

15 Peraturan Menteri Pendidikan Nasional Republik Indonesia Nomor 58 Tahun 2009, Tentang Standar Pendidikan Anak Usia Dini 
anak diibaratkan seperti kertas tisu yang menyerap air dan dengan bertambahnya usia maka kognitif anak akan sempurna untuk dapat berpikir kritis ${ }^{16}$.

Pendidikan multikultural memiliki peran penting bagi tumbuh kembangnya karakter anak usia dini. Karakter yang diharapkan adalah karakter ke-Indonesian. Adanya karakter ke-Indonesian yang telah ditanamkan sejak dini pada anak-anak akan memberikan konstribusi yang positif bagi perkembangan pribadi anak hingga dewasa nanti, seperti saling hormat-menghormati satu dengan yang lainnya, memiliki sikap nasionalisme, bertaqwa, cerdas, berbudi luhur, memiliki akhlak yang baik, bersikap tepo selero, menghormati perbedann dan lain-lain ${ }^{17}$. Bertalian dengan pendapat ini, Suyanto mengatakan bahwa pengembangan sikap multkultural dalam menciptakan generasi yang memiliki kepribadian dan jiwa lintas antarbudaya merupakan hal yang sangat krusial perlu ditanamkan sejak anak berusia dini ${ }^{18}$.

Pentingnya pendidikan multikultural pada anak usia dini yang diterapkan pada sekolah formal dan nonformal serta perlunya revitalisasi rasa kebangsaan disebakan oleh beberapa hal ;

1. Runtuhnya orde baru menyebabkan terjadinya diintegrasi antar anak bangsa, kesengsaraan, kemiskinan, pelanggaran hukum, rusaknya mental, korupsi, premanisme, kriminalisme terjadi di manamana. Rusaknya mental anak bangsa yang tidak memandang toleransi, perbedaan kulturalisme, pluralisme sesama semakin melunturkan rasa nasionalisme antar sesama. Untuk itu dipandang penting merevitalisasi kembali jiwa nasionalisme

${ }^{16}$ Slamet Suyanto. (2005).Dasar-dasar Pendidikan Anak Usia Dini. Yogyakarta: Hikayat Publishing.h.19

${ }^{17}$ Joko Sutarto. "PENTINGNYA PEMBELAJARAN MULTIKULTURAL PADA PENDIDIKAN ANAK USIA DINI," 6. http://journal.unnes.ac.id/nju/index.php/edukasi/ article/view/.h.6

${ }_{18}$ Suyanto, Slamet. 2005. Konsep Dasar Pendidikan Anak Usia Dini. Jakarta: Depdiknas.h.8 anak bangsa melalui jalur pendidikan. Dengan pendidikan para generasi muda akan memiliki kembali rasa nasionalisme yang tinggi, toleransi dengan sesame dengan tidak memandang perbedaan sebagai sesuatu yang mengancam tetapi memandang perbedaan sebagai sebuah keberagaman.

2. Perbedaan agama, ras, suku, jenis kelamin, sosial ekonomi yang kurang diperhatikan oleh pemerintah daerah dan pemerintah menyebabakan pergesekan yang tidak dapat dihindari lagi di masyarakat. Upayaupaya mengurangi pergesekan tersebut tidak menjadi agenda prioritas pemerintah bahkan dianggap adanya usaha menentang pemerintah.

3. Kurangnya perhatian dari pemerintah terhadap pelanggaran HAM di masyarakat

4. Penyalahgunaan peran dan dwifungsi ABRI di masyarakat sehingga menyebabkan diintegrasi nasional antara ABRI dan masyarakat umum. Pengembalian peran ABRI yakni kembali lagi ke barak yang terfokus pada pengamanan negara meminimalisir perpecahan di kalangan pengamanan negara dan masyarakat

\section{Pembelajaran Bahasa Inggris Berbasis Multikultural melalui Media Dongeng}

Berdasarkan hasil penelitian oleh English First atau yang kita kenal dengan nama $\boldsymbol{E} \boldsymbol{F}$ pada negaranegara yang menggunakan bahasa Inggrisnya sebagai bahasa keduanya menyatakan bahwa kemampuan berbahasa Inggris bangsa Indonesia berada diurutan ke-25. Ini menyiratkan bahwa ketidakmampuan bangsa Indonesia bisa bersaing dengan negara-negara yang juga menggunakan bahasa Inggris sebagai English as a foreign language. Bahkan menurut laporan penel itian ini juga, Malaysia berada diurutan ke-11. 
Melihat kenyataan ini, bukanlah hal yang mudah bagi bangsa Indonesia mengejar ketertinggalan tersebut dari negara-negara lain. Tetapi keterpurukan ini bukanlah harga mati bagi bangsa kita untuk mengejar ketertinggalan ini, bahkan mulai adanya proses perbaikan pembelajaran dan pengajaran lainnya, baik dari sisi kurikulum, guru dan fasilitas penunjang lainnya. Dengan diterbitkannya SK menteri Pendidikan dan kebudayaan No.060/U/1993 tanggal 25 Februari 1993 tentang dimungkinkannya pelajaran bahasa Inggris sebagai pelajaran muatan lokal dan dapat dimulai pada kelas 4 SD (Depdiknas). Hal ini memberikan angin segar bagi pembelajaran bahasa Inggris di pendidikan dasar mulai dari PAUD, TK dan sekolah dasar untuk memasukkan budaya lokal dalam materi bahasa Inggris. Diharapkan dengan masuknya budaya lokal ke dalam materi pembelajaran bahasa Inggris di PAUD, TK dan sekolah dasar, siswa dapat memiliki sikap toleransi dengan budaya dari daerah lain.

Pembelajaran bahasa Inggris berbasis multikultural bagi anak usia dini diberikan dalam bentuk dongeng, Cerita terutama tentang kejadian zaman dahulu yang aneh-aneh atau cerita yang tak terjadi ${ }^{19}$, Dongeng merupakan cerita-cerita jaman purba yang berbentuk prosa, yaitu tentang cerita khayal dan penuh keajaiban ${ }^{20}$. Dongeng selain memberikan hiburan pada anak-anak, juga dapat dijadikan ajang pendidikan moral bagi anakanak. Penggunaan dongeng untuk meningkatkan kemampuan anak dalam berbicara dan menyimak sangat dianjurkan. Karena dengan media ini anak akan bertambah kosakatanya, keberanian untuk mengepresikan diri, menimbulkan kepercayaan diri anak membangun komunikasi dengan orang lain di sekitarnya.

19 Oerwadarminta . 1985. Kamus Umum Bahasa Indonesia. Jakarta: Balai Pustaka.h.357

20 Surana. 2001. Pengantar Sastra Indonesia . Solo. Tiga serangkai.h. 42
Berdasarkan jenisnya, dongeng dibedakan atas:

1. Dongeng tradisional, yaitu dongeng yang berasal dari cerita rakyat mengenai asalusul cerita terjadinya sebuah desa atau daerah

2. Dongeng futuristik atau modern adalah dongeng yang mengandalkan imajinasi masa depan

3. Dongeng pendidikan adalah dongeng berfungsi untuk memberikan pengetahuan untuk perbaikan tingkah laku sesorang

4. Dongeng fable adalah dongeng yang bersumber mengani hewan yang dapat berbicara dan bertingkah laku seperti manusia.

5. Dongeng sejarah, yaitu dongeng mengenai sejarah tokoh pahlawan atau peristiwaperistiwa penting dan sebagainya.

6. Dongeng tarapi adalah dongeng yang digunakan untuk mengobati orang yang mengalami trauma terhadap suatu kejadian atau peristiwa, seperti korban tsunami di Aceh, gempa bumi di Yogyakarta dan lainlain, ${ }^{21}$

Di bawah ini salah satu contoh dongeng tradisional bahasa Inggris dari daerah Jawa Barat yang berjudul 'Roro Jonggrang' .

Roro Jonggrang was the daughter of King Prabu $B a k a$, who ruled over the ancient Javanese kingdom of Prambanan. The king was killed in a fierce battle by the minister of the King of Pengging, who fought with a magic weapon called 'Bandung'. For this reason, he was known as 'Bandung Bandawasa'.

Not long afterwards, Bandung Bandawasa decided to marry Princess Roro Jonggrang, the daughter of his victim. But she had no desire to marry the murderer of her father, so she sought the advice of the Patih. The Patib made a wise suggestion. Bandung would have to build a thousand temples and two deep weels. If he managed to complete all this in the course of one night, he could marry

${ }^{21}$ Al-Qudsy, Muhaimin, dan Ulfah Nurhidayah. 2010. Mendidik Anak Lewat Dongeng. Yogyakarta: Madania.h.114 
the princess. Bandung knew two people possessing magic powers who promised to help him. one was his father, "Damarmaya", and the other was mighty King of Pengging. A date was fixed and in the evening, Bandung's followers began their giant construction job. Five hundred temples were completed by midnight.

Roro Jonggrang sent a man to watch the progress of Bandung's work and by four o'clock in the morning he saw that nine hundred and ninety five temples were already built and to deep wells nearly finished. The whole palace was filled with sadness, because the Princess would have to marry the man who had murdered her father. Again the Patih had an idea. He woke up all the young girls and ordered them to pond rice at once. When the workers heard the pounding of rice and smelt the flowers, which were the signs of dawn they stopped their work. Bandung Bandawasa was glad to see the temples before him and counted them himself. But to his surprise, there were only 999 temples22.

Adapun terjemahannya sebagai berikut ;

Roro Jonggrang adalah anak perempuan dari Raja Prabu Baka, yang memimpin kerajaan Jawa atas Prambanan pada dahulu kala. Raja tersebut terbunuh pada pertempuran sengit oleh menteri dari kerajaan Pengging, yang bertarung menggunakan senjata magis bernama 'Bandung'. Karena alasan inilah ia dikenal sebagai 'Bandung Bandawasa'. Tak berselang lama, Bandung Bandawasa memutuskan untuk menikahi putrid Roro Jonggrang, anak dari musuhnya. Tetapi Roro Jonggrang tidak berkeinginan untuk menikah dengan seseorang yang telah membunuh ayahnya, sehingga ia meminta saran kepada Patih. Patih membuat sebuah saran yang bijaksana. Bandung diminta untuk membangun seribu candid an dua sumur yang dalam. Jika ia mampu menyelesaikannya dalam satu malam, maka ia dapat menikahi Roro Jonggrang. Bandung tahu dua orang yang memiliki kekuatan magis yang berjanji akan membantunya. Salah satunya adalah ayahnya, "Darmamaya", dan satunya lagi adalah Raja Pengging. Waktupun telah ditentukan, dan pada waktu petang, pengikut Bandung memulai pembangunan dengan jin pekerja. Lima ratus

${ }^{22}$ http://www.bahasainggrisoke.com/generic-structurenarrative-text-tentang-roro-jonggrang-beserta-rtinya/ candi telah terselesaikan sampai pertengahan malam.

Roro Jonggrang mengirim seseorang untuk mematai-matai perkembangan dari pekerjaan Bandung dan pada pukul empat pagi, dia melihat sudah ada Sembilan ratus Sembilan puluh lima candi yang telah dibuat dan dua sumur yang dalam hampir selesai. Seluruh isi kerajaan menjadi sedih, karena putrid harus enikah dengan seorang yang telah membunuh ayahnya. Lagi-lagi, Patih memiliki ide. Dia membangunkan semua gadis dan memintanya menumbuk padi bersamaan. Ketika para pekerja mendengar tumbukan padi dan mencium aroma bunga, yang mana merupakan tanda fajar, mereka pun menghentikan pekerjaan mereka. Bandung Bandawasa bahagia melihat candi-candi itu sampai pada akhirnya dia menghitungnya. Tetapi betapa terkejutnya ia, hanya ada 999 candi.

Dongeng di atas adalah jenis dongeng tradisonal. Dongeng tradisional cerita Roro Jongrang ini berasal dari daerah Jawa Tengah yang merupakan cerita lokal warisan nenek moyang. Dongeng tradisional ini merupakan potret cerita rakyat Jawa Tengah pada masa lalu. Cerita ini mengajarkan kepada anak tentang pentingnya anak memahami kultur atau lintas budaya dari daerah lain di Indonesia. Pesan moral pada cerita ini adalah bahwa kekuatan sosok Bondowoso yang perkasa dan sangat ditakuti bisa dikalahkan dengan siasat 'pemberontakan yang lembut' dari seorang sosok Roro Jongrang. Sikap penolakan Roro Jongrang terhadap cengkeraman patriarkhal pada sosok Bondowoso yang suka memaksakan kehendaknya tidak baik untuk diikuti. Sikap lemah-lembutnya Roro Jongrang dan siasat yang dimilikinya dapat menakluhkan sosok Bondowoso yang keji.

Pemberian dongeng pada anak usia dini sangatlah bermanfaat bagi perkembangan bahasa sianak. Kemampuan bahasa meliputi kemampuan membaca, menulis, menyimak dan berbicara. Pada anak usia dini kemampuan bahasa yang berkembaang adalah kemampuan menyimak dan berbicara. Melalui pemberian dongeng pada anak- 
anak, mereka dapat berkomunikasi dengan orang lain, berimajinasi dan mengepresikan daya imajinasi serta perasaannya mereka melalui apa yang mereka simak dari dongeng tersebut.

Pada salah satu contoh dongeng di atas 'Roro Jongrang' terdapat tiga hal penting yang dapat diajarkan kepada anak. Pertama, dongeng ini memberikan nilai moral yang positif ke anak bahwa sikap Bondowoso yang keras dan keji bukanlah hal yang terpuji untuk diikuti sehingga dengan pemberian pengertian dan penjelasan akan membentuk keperibadian anak menjadi lebih baik. Kedua, pengenalan bahasa Inggris pada anak-anak sejak dini sangat penting karena anak lebih cepat belajar bahasa Inggris disbanding orang dewasa. Dengan pengenalan kosakata bahasa Inggris, seperti kata Princess Roro Jonggrang, King Prabu Baka, kingdom of Prambanan dan lain-lainnya. Pengenalan kosakata bahasa Inggris tersebut diberikan dengan cara bercerita akan menambah motivasi anak untuk belajar bahasa Inggris dengan cara mengucapkannya, dan keberanian anak berbicara dalam bahasa Inggris semakin meningkat. Ketiga, pengenalan lintas budaya dalam bentuk mengenalkan anak pada budaya daerah lain akan menanamkan jiwa toleran terhadap budaya lain yang berbeda dengan budaya yang dimilikinya.

\section{Kesimpulan}

Pengenalan multikultural dan lintas budaya pada anak usia dini sangat penting, khususnya pengenalan lintas budaya pada bahasa Inggris. Dengan pengenalan multikultural dan lintas budaya sejak dini diharapkan anak akan memiliki rasa toleran dengan budaya lain yang bukan budayanya. Salah satu pengenalan lintas budaya dalam bahasa Inggris adalah melalui media dongeng. Penggunaan media dongeng pada anak usia dini, selain meningkatkan kognitif anak, pengembangan bahasa anak, juga akan menumbuhkan rasa percaya diri pada diri anak, meningkatkan kreativitas, memecahkan masalah, berinteraksi dengan orang lain dengan kerangka budaya lokal.

\section{Daftar Pustaka}

Al-Qudsy, Muhaimin, dan Ulfah Nurhidayah. 2010. Mendidik Anak Lewat Dongeng. Yogyakarta: Madania.

Hurlock, Elizabeth B. 1998. Perkembangan Anak jilid 1. Jakarta: Erlangga Jakarta: Erlangga.

Boediono. 2002. Kurikulum dan Hasil Belajar. Jakarta : Depdiknas.

Brown, H.D. 1987. Principles of Language Learning and Teaching: Englewood Cliff:Prentice Hall.

Dedi Irwansyah.Pendidikan Multikultural dan Pengajaran Bahasa Asing. Jurnal Addin, Vol. 7, No. 1, Februari 2013.

Hamzah B. Uno, 2006. Orientasi Baru Dalam Psikologi Pembelajaran, Jakarta: Bumi Aksara.

http://www.bahasainggrisoke.com/genericstructure-narrative-text-tentang-rorojonggrang-beserta-rtinya/

Joko Sutarto. "Pentignya Pembelajaran Multikultural Pada Pendidikan Anak Usia Dini," 6. http:// journal.unnes.ac.id/nju/index.php/edukasi/ article/view/.

Muhibbin Syah, 2007. Psikologi Belajar . Jakarta: PT. RajaGrafindo Persada. 2007.

Oerwadarminta . 1985. Kamus Umum Bahasa Indonesia. Jakarta: Balai Pustaka. 
Stephen D.Krashen, 1972."Laterization, Language, Learning and the Critical Period: Some New Evidence." Language Learning, Vol.23.

Surana. 2001. Pengantar Sastra Indonesia . Solo. Tiga serangkai.

Paul Henry, dkk, 1994. Perkembangan dan Kepribadian Anak, jilid II, Terjemahan Med Meitasari Tjandrasa Jakarta, Erlangga,

Peraturan Menteri Pendidikan Nasional Republik Indonesia Nomor 58 Tahun 2009, Tentang Standar Pendidikan Anak Usia Dini

Slamet Suyanto. 2005.Dasar-dasar Pendidikan Anak Usia Dini. Yogyakarta: Hikayat Publishing.
Sujiono, Bambang, 2015. Metode Pengembangan Fisik, Tangerang Selatan:Universitas Terbuka.

Sutjihati Somantri, 2006. Psikologi Anak Luar Biasa, Bandung: PT.Refika Aditama.,

Suyanto, Slamet. 2005. Konsep Dasar Pendidikan Anak Usia Dini. Jakarta: Depdiknas.

Undang-Undang No. 20 Tahun 2003. Tentang Sistem Pendidikan Nasio-nal.Jakarta: Gramedia.

Wiwik Pudjaingsih. Metode Pengembangan Bahasa: Penerapannya pada Pembelajaran Berbasis Tema dan Sentra di Taman Kanakkanak. Jurnal Pena. Vol.3 No.2. Desember 2013. ISSN.2089-3973. 